
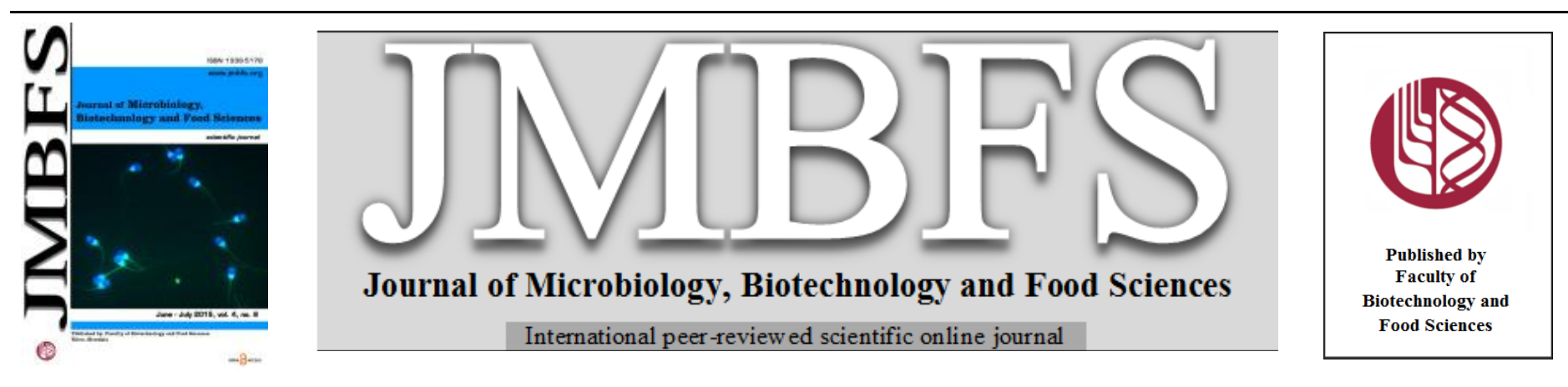

\title{
EVALUATION OF THE DISINFECTION EFFECTIVENESS AT MEAT PROCESSING BY THE TWO METHODS
}

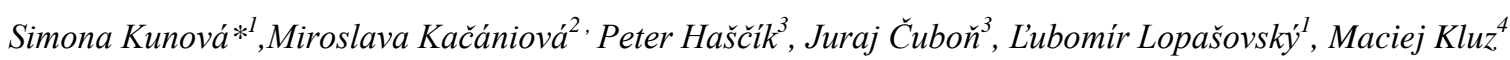

\section{Address(es):}

${ }^{1}$ Slovak University of Agriculture in Nitra, Faculty of Biotechnology and Food Sciences, Department of Food Hygiene and Safety, Tr. A. Hlinku 2, 94976 Nitra, Slovak Republic.

${ }^{2}$ Slovak University of Agriculture in Nitra, Faculty of Biotechnology and Food Sciences, Department of Microbiology, Tr. A. Hlinku 2, 94976 Nitra, Slovak Republic. ${ }^{3}$ Slovak University of Agriculture, Faculty of Biotechnology and Food Sciences, Department of Animal Products Evaluation and Processing, Tr. A. Hlinku 2, 94976 Nitra, Slovak Republic.

${ }^{4}$ Department of Biotechnology and Microbiology, Faculty of Biology and Agriculture, University of Rzeszow, Zelwerowicza 4, 35-601,

Rzeszow, Poland.

*Corresponding author: simona.kunova@gmail.com

doi: 10.15414/jmbfs.2015.4.6.564-567

\section{ARTICLE INFO}

Received 23. 4. 2015

Revised 29. 5. 2015

Accepted 30. 5. 2015

Published 1. 6. 2015

\section{Regular article}

OPEN $\partial_{\text {ACCESS }}$

\section{ABSTRACT}

The aim of this article was the control of disinfection in selected meat processing-plant by two methods - swabbing method and The $3 \mathrm{M}^{\mathrm{TM}}$ Petrifilm${ }^{\mathrm{TM}}$ plates. Samples were collected within three months (September, October, November 2014). Together 54 samples selected surfaces were collected. Each month six samples were collected using imprint method with Petrifilm plates on total count of microorganisms, 6 samples using imprint method with Petrifilm plates on the number of coliforms and 6 samples using sterile swab method. Samples were collected from the workbench, conveyor belt, cutting blades, meat grinder, wall and knife. Total viable counts (TVC) and coliform bacteria (CB) were determined in samples. The values of TVC in September obtained by swabbing method were higher than allowable limit in sample no. $1\left(3.70 \times 10^{2} \mathrm{CFU} . \mathrm{cm}^{-2}\right)$ and in sample no. $4\left(3.35 \times 10^{1} \mathrm{KTJ} . \mathrm{cm}^{-2}\right)$. The values of TVC obtained by Petrifilm plates were lower than 10 CFU. $\mathrm{cm}^{-2}$ in all samples. Values of CB obtained by Petrifilm plates were lower than $1 \mathrm{CFU} . \mathrm{cm}{ }^{-2}$ in all samples, CB obtained by swabbing method was $1.6 \times 10^{1}$ CFU.cm ${ }^{-2}$ in sample no. 6 . Values of TVC obtained in October by Petrifilm plates and also by swabbing method were higher than permissible limit $\left(<10 \mathrm{CFU} . \mathrm{cm}^{-2}\right)$ in sample no. 2 and sample no. 4 . Values of CB obtained by Petrifilm plates were lower than 1 CFU.cm ${ }^{-2}$ in all samples, CB obtained by swabbing method was $3,65 \times 10^{1}$ CFU. $\mathrm{cm}^{-2}$ in sample no. 3 , value of $\mathrm{CB}$ obtained by swab method in sample no. 3 does not meet requirements of internal company standards. Values of TVC obtained in November by Petrifilm plates were lower than $10 \mathrm{CFU} . \mathrm{cm}^{-2}$ in all samples. TVC otained by swab method were $1,25 \times 10^{1}$ CFU.cm ${ }^{-2}$ in sample no. 3 and $3,25 \times 10^{1}$ CFU.cm ${ }^{-2}$ in sample no. 4. Samples were not in accordance with requirements of internal company standards. Values of $\mathrm{CB}$ obtained in November by Petrifilm plates and by swabbing method were after disinfection lower than 1 CFU. $\mathrm{cm}^{-2}$ in all samples.

Keywords: disinfection, total viable count, coliform bacteria, Petrifilm plates, swabbing method

\section{INTRODUCTION}

Many food pathogenic and spoilage bacteria are able to attach to food contact surfaces (Fonnesbech Vogel $\boldsymbol{e t}$ al., 2001), and remain viable even after cleaning and disinfection (Frank and Koffi, 1990). Such adhered bacteria can detach during production and contaminate food as it passes the surfaces. This can seriously effect the quality and safety of the processed food and pose a potential risk to the consumer, particularly if contamination occurs after a bactericidal step, such as cooking.

In order to ensure the highest possible hygiene standards in meat, poultry and egg factories, it is essential that each one is cleaned and disinfected regularly. In most factories, this is carried out at the end of the day's processing. Production is stopped, gross debris is removed and then the plant is cleaned with detergents, before being rinsed with water and disinfected. Many factories also clean during staff breaks and this is known as 'mid-shift cleaning'. The effectiveness of cleaning can be extremely variable. It will depend on the training and commitment of the personnel, both those on the production lines and others responsible for the cleaning process itself. In a well-run factory, sufficient time is set aside to ensure a thorough and effective clean, and the whole process is properly documented, using appropriate check lists; furthermore, the cleaning operatives are specially trained, thus providing maximum effectiveness. The importance of ensuring that the whole factory is thoroughly cleaned and disinfected cannot be over-emphasised. The aim of this study was to compare two methods of disinfection control at meat processing (Rigarlsford, 2007).

Cleaning and disinfection (C\&D) are among the most important hazard control measures in the meat industry, it is thus of prime importance to assess their efficacy. However, this is a difficult task because C\&D cannot remove all microbial cells present on open surfaces. Efficacy of C\&D can be assessed by agar contact plating, a convenient and frequently used method that nevertheless underestimates CFU counts on surfaces (Bagge-Ravn et al., 2003).

Swabbing surfaces to detach microbial cells for quantification is more accurate but does not remove all cells (Oulahal-Lagsir et al., 2000). Efficiency of swabbing depends on the operator, the swabbing material, the microbial species and the history of the attached cells.

In the food industry, European legislation requires that surfaces should be "in a sound condition and must be easy to clean". Microbiological surface control is ensured in the food process environment provided it is hygienically designed and that adequate hygiene procedures are implemented (Verran et al., 2001). However, insufficient cleaning and disinfection of food contact surfaces represent a potential risk of cross-contamination to food (Mattila et al., 1990). Therefore, any lack of hygiene management may lead to a reduction in food shelf-life with adverse economic and public health consequences (Moore and Griffith, 2002a). Several studies have shown that various foodborne pathogens such as Escherichia coli, Staphylococcus aureus or Listeria monocytogenes can survive for hours or even days on hands, sponge/cloths, or utensils (Kusumaningrum et al., 2003; Wilks et al. 2005). Various methods of detection and enumeration of microorganisms from surfaces are currently available. Microbiological methods including hygiene swabbing or agar contact methods are traditionally employed to assess the cleanliness of surfaces. However, despite the simplicity of use, microbiological testing is limited by incubation steps of $24-48 \mathrm{~h}$ whereas results may be needed earlier, ideally prior to the release of the food product to market. The aim of the present study was to compare two methods of disinfection control at meat processing. 


\section{MATERIAL AND METHODS}

The aim of this article was to compare the swab method and fingerpront method, which are used to control of disinfection eficacy in food industry. Control of disinfection eficacy was carried out in the meat processing. Fingerprints by Petrifilm plates and swabs were carried out after disinfection from the following surfaces: workbench - sample no. 1 , conveyor belt - sample no. 2 , cutting blades - sample no. 3, meat grinder - sample no. 4, wall - sample no. 5, knife - sample no. 6. Total viable counts (TVC) and coliform bacteria (CB) were determined after disinfection of selected surfaces. Sodium hypochlorite $(4.7 \%)$ was used to disinfection of surfaces.

\section{Taking of samples}

Together 54 samples were taken from selected surfaces after disinfection during three month. There were taken six fingerprints by Petrifilm plates to determination of TVC, six fingerprints by Petrifilm plates to determination of $\mathrm{CB}$ and six swabs each month after disinfection.

\section{Determination of cfu counts by Petrifilm plates}

The Petrifilm Aerobic Count plate is a reliable, ready made medium system for enumerating total aerobic bacteria populations. Petrifilm Aerobic Count plates contain Standard Methods nutrients, a cold water soluble gelling agent and a tetrazolium indicator dye which facilitates colony enumeration.

Petrifilm plates contain special media that must be hydrated before application. Hydratation is carried out by pipetting $1 \mathrm{ml}$ peptone solution to the middle of the Petrifilm plate. Fingerprints were performed by placing Petrifilm plates to examined surface. Cultivation was carried out in thermostats at temperature 30 ${ }^{\circ} \mathrm{C}$ for 48 hours (determination of TVC) and at $37{ }^{\circ} \mathrm{C}$ for 24 hours (determination of $\mathrm{CB}$ ). All red dots regardless of size or intensity should be counted as colonies. The circular growth area is approximately $20 \mathrm{~cm}^{2}$. The results were converted to CFU.cm ${ }^{-1}$.

\section{Determination of cfu counts by swab method}

Sterile swabs were used for the sampling from surfaces and equipments. Swabs were placed in a test tube with $9 \mathrm{ml}$ of physiological solution. Swabs were performed by gentle rubbing in area $20 \mathrm{~cm}^{2}$ from controlled surface. Swabs with samples were placed in a transport medium. Dilution plating method was used to determine the microorganisms. Inoculation was performed with a sterile pipette $1 \mathrm{ml}$ of triple repeats (parallel to the three Petri dishes) for each dilution used Dilutions $10^{-3}$ and $10^{-4}$ were used to determination of total viable counts.

Plate Count Agar was used for determine of Total Viable Counts in samples. Petri dishes were cultivated upside-down in a thermostat at $30{ }^{\circ} \mathrm{C}$ for $48-72$ hours under aerobic conditions. Dilutions of $10^{-1}$ and $10^{-2}$ were used to determine the number of coliform bacteria. Violet red bile agar was used for determine of Coliform Bacteria in samples. Petri dishes were cultivated upside-down in a thermostat at $37^{\circ} \mathrm{C}$ for $24-48$ hours. The results were converted to CFU.cm ${ }^{-1}$.

\section{Evaluation of CFU counts}

Characteristic colonies on the Petri dishes and the Petrifilm plates were counted after cultivation. Results were evaluated according to Regulation of Slovak Republic (SR) no. 281/2003 as follows:

TVC - acceptable range - 0-10 CFU.cm ${ }^{-2}$

$\mathrm{CB}$ - acceptable range - 0-1 CFU.cm ${ }^{-2}$

\section{RESULTS AND DISCUSSION}

Control of disinfection was carried out at meat processing during three month (September 2014, October 2014 and November 2014). Two methods of disinfection control were compared - swab method and method by Petrifilm plates.

Bacterial recovery from surfaces using swabbing techniques may be influenced by several factors such as the ability of the swab to remove the microorganisms from the surface, their effective release from the swab and subsequent recovery using plating or other techniques (Moore and Griffith, 2002a).

\section{Evaluation of microorganisms in September 2014}

The values of TVC obtained by Petrifilm plates were lower than 10 CFU.cm ${ }^{-2}$ in all samples. Values of TVC obtained by swab method were $3.70 \times 10^{2}$ CFU.cm ${ }^{-2}$ in sample no. 1 (workbanch) and $3.35 \times 10^{1} \mathrm{CFU}_{\mathrm{cm}}{ }^{-2}$ in sample no. 4 (meat grinder). TVC in samples no. 2, 3, 5 and 6 were lower than 10 CFU.cm ${ }^{-2}$ (tab. 1) Values of TVC in sample no. 1 and 4 were not in accordance with requirements of Regulation of SR no. 281/2003.

The removal of bacteria from dry surfaces can be improved using a premoistened swab as confirmed by Moore and Griffith (2002b). In the present study, swabs were impregnated with a commercial solution (SRK) or Ringer $1 / 4$ strength solution. The SRK solution contained in a swab tube is a non-nutrient phosphate buffered solution purporting to include substances that neutralize and inactivate disinfectants and sanitizing agents. This non-nutrient, phosphate buffered solution enables quantification of microorganisms when transported at ambient temperature.

Bazaco et al. (2007) advised the use of Copan SRK solution for quantifying microbial recoveries as confirmed by Moore and Griffith (2007) for the recovery of $E$. coli and $S$. aureus. Moreover, the use of cotton swabs associated with Ringer $1 / 4$ strength solution has been demonstrated to be advantageous (Moore and Griffith, 2002c). Analysis of naturally contaminated surfaces generally involves the use of traditional plate counting or $3 \mathrm{M}$ Petrifilm ${ }^{\mathrm{TM}}$. The latter is frequently used by the food industry for the enumeration of L. monocytogenes, $S$. aureus and the Enterobacteriaceae in foods or from surfaces with bacterial recoveries comparable to traditional plating methods (Fedio et al., 2008; Paulsen et al., 2008 and Vicosa et al., 2010).

Table 1 Determination of TVC in September 2014

\begin{tabular}{|c|c|c|}
\hline \multirow[t]{2}{*}{ Samples } & \multicolumn{2}{|c|}{ TVC (CFU.cm²) } \\
\hline & Petrifilm plate & Swab method \\
\hline 1 & $<10$ & $3.70 \times 10^{2}$ \\
\hline 2 & $<10$ & $<10$ \\
\hline 3 & $<10$ & $<10$ \\
\hline 4 & $<10$ & $3.35 \times 10^{1}$ \\
\hline 5 & $<10$ & $<10$ \\
\hline 6 & $<10$ & $<10$ \\
\hline
\end{tabular}

Values of $\mathrm{CB}$ obtained by Petrifilm plates were lower than 1 CFU.cm ${ }^{-2}$ in all samples, CB obtained by swab method was $1.6 \times 10^{1}$ CFU. $\mathrm{cm}^{-2}$ in sample no. 6 (knife), all others samples were negative for presence of coliform bacteria (tab. 2). Only sample no. 6 does not meet requirements of Regulation of SR no. $281 / 2003$.

In the study of Martinon et al. (2012) data showed that L. monocytogenes was not detected but some non-presumptive colonies were found on $3 \mathrm{M}$ Petrifilm $^{\mathrm{TM}}$ Listeria Count Plate and LSA for 4 samples collected inside a food filling dispenser within the factory. It is reasonable to suggest that the microorganism involved may be Listeria species but not L. monocytogenes S. aureus was not detected either, despite the presence of black colonies on Baird Parker; however these tested coagulase negative, and originated from a sample collected inside a large empty food container undergoing a cleaning process. However, the presence of Enterobacteriaceae, using plating and Petrifilm ${ }^{\mathrm{TM}}$ methods, was confirmed from surface samples. Characteristic colonies of Enterobacteriaceae were observed in samples collected from hoppers, exposed machine surfaces or cylinders of machines. The tests performed on the subcultures showed that the bacteria were oxidase negative and positive for glucose fermentation.

Table 2 Determination of CB in September 2014

\begin{tabular}{lcc}
\hline Samples & \multicolumn{2}{c}{ CB $\left(\right.$ CFU.cm $\left.^{-2}\right)$} \\
\hline & Petrifilm plate & Swab method \\
$\mathbf{1}$ & $<1$ & $<1$ \\
$\mathbf{2}$ & $<1$ & $<1$ \\
$\mathbf{3}$ & $<1$ & $<1$ \\
$\mathbf{4}$ & $<1$ & $<1$ \\
$\mathbf{5}$ & $<1$ & $<1$ \\
$\mathbf{6}$ & $<1$ & $\mathbf{1 . 6} \times \mathbf{1 0}$ \\
\hline
\end{tabular}

The quantification of Enterobacteriaceae was not available for a majority of naturally contaminated samples, as parts of machinery were not flat so a template could not be applied. Some studies have related issues associated with bacterial recoveries from dry surfaces using swabbing techniques (Davidson et al., 1999) Moore and Griffith (2002c) explained that the efficiency of the swabbing technique was lower when sampling dry surfaces compared with wet surfaces as microbial viability may be affected by drying.

\section{Evaluation of microorganisms in October 2014}

Values of TVC obtained in October by Petrifilm plates were $1,6 \times 10^{1} \mathrm{CFU} . \mathrm{cm}^{-2}$ in sample no. 2 (conveyor belt) and $1.2 \times 10^{1}$ CFU.cm ${ }^{-2}$ in sample no. 4 (meat grinder). Values were higher than permissible limit $\left(<10\right.$ CFU.cm $\left.{ }^{-2}\right)$. TVC in samples no. 1, 3, 5 and 6 were lower than 10 CFU.cm ${ }^{-2}$. TVC obtained by swab method were $4.35 \times 10^{1}$ CFU.cm ${ }^{-2}$ in sample no. 2 and $2.48 \times 10^{2}$ CFU.cm ${ }^{-2}$ in sample no. 4, TVC in samples no. $1,3,5$ and 6 were lower than 10 CFU.cm ${ }^{-2}$ (tab. 3). These results are similar to results obtained by Petrifilm plates. 
Table 3 Determination of TVC in October 2014

\begin{tabular}{|c|c|c|}
\hline \multirow[t]{2}{*}{ Samples } & \multicolumn{2}{|c|}{ TVC $\left(\right.$ CFU.cm $\left.{ }^{-2}\right)$} \\
\hline & Petrifilm plate & Swab method \\
\hline 1 & $<10$ & $<10$ \\
\hline 2 & $1.6 \times 10^{1}$ & $4.35 \times 10^{1}$ \\
\hline 3 & $<10$ & $<10$ \\
\hline 4 & $1.2 \times 10^{1}$ & $2.48 \times 10^{2}$ \\
\hline 5 & $<10$ & $<10$ \\
\hline 6 & $<10$ & $<10$ \\
\hline
\end{tabular}

Values of $\mathrm{CB}$ obtained by Petrifilm plates were lower than 1 CFU. $\mathrm{cm}^{-2}$ in al samples, CB obtained by swab method was $3.65 \times 10^{1}$ CFU.cm ${ }^{-2}$ in sample no. 3 (cutting blades), coliform bacteria were lower than 1 in other samples (tab. 4). Value of $\mathrm{CB}$ obtained by swab method in sample no. 3 does not meet requirements of Regulation of SR no. 281/2003.

Jessen and Lammert (2003) measured the aerobic counts of cleaned and disinfected surfaces of processing lines for sliced cooked ham products and found values as high as $10^{4}$ CFU.cm ${ }^{-2}$. Similarly, Bizzaro et al. (1990) found more than $10^{4} \mathrm{CFU} . \mathrm{cm}^{-2}$ on cleaned and disinfected polyurethane conveyor belts for delicatessen products.

Table 4 Determination of CB in October 2014

\begin{tabular}{|c|c|c|}
\hline \multirow[t]{2}{*}{ Samples } & \multicolumn{2}{|c|}{ CB $\left(\right.$ CFU.cm $\left.{ }^{-2}\right)$} \\
\hline & Petrifilm plate & Swab method \\
\hline 1 & $<1$ & $<1$ \\
\hline 2 & $<1$ & $<1$ \\
\hline 3 & $<1$ & $3.65 \times 10^{1}$ \\
\hline 4 & $<1$ & $<1$ \\
\hline 5 & $<1$ & $<1$ \\
\hline 6 & $<1$ & $<1$ \\
\hline
\end{tabular}

Marouani-Gadri et al. (2009) investigated the effects on Escherichia coli O157:H7 biofilm formation of bacteria isolated from meat site surfaces following cleaning and disinfection. Samples were obtained by swabbing the surfaces of equipment or floors over areas ranging from 315 to $3200 \mathrm{~cm}^{2}$ in a slaughter hall, a meat cutting room and a meat boning room of a meat-processing plant. The number of bacteria recovered from these surfaces ranged from $<1$ to $>10^{5}$ CFU. $\mathrm{cm}^{-2}$. In the slaughter hall, stainless steel was in one case one of the most contaminated materials and in other cases one of the less contaminated. The same observation was made for conveyor belts made of polyvinyl chloride in the boning room. Dominant genera in the meat plant were Staphylococcus and Bacillus which were both $34 \%$ of the isolates from the slaughter hall and 14 and $4 \%$ respectively of the isolates from the cutting room. Randomly selected isolates of each of the genera recovered from the slaughter hall were cultured with E. coli $\mathrm{O} 157: \mathrm{H} 7$ in meat exudate at $15{ }^{\circ} \mathrm{C}$ to form dual-organism biofilms on polyurethane. In all cases but one, the isolates increased the numbers of attached $E$. coli $\mathrm{O} 157: \mathrm{H} 7$. The effects ranged from 0.37 to 1.11 for EDL 933 strain and from 0.19 to $1.38 \log \left(\right.$ CFU.cm $\left.{ }^{-2}\right)$ for Sakaï strain. This is the first time that a resident microbiota of a meat-processing plant has been shown to have a favourable effect on E. coli $\mathrm{O} 157: \mathrm{H} 7$ colonization of a solid surface, which is of great interest from a food safety standpoint.

\section{Evaluation of microorganisms in November 2014}

Values of TVC obtained by Petrifilm plates were lower than 10 CFU.cm ${ }^{-2}$ in all samples. TVC otained by swab method were $1.25 \times 10^{1}$ CFU. $\mathrm{cm}^{-2}$ in sample no. 3 (cutting blades) and $3.25 \times 10^{1}$ CFU.cm ${ }^{-2}$ in sample no. 4 (meat grinder) (tab. 5). Samples were not in accordance with requirements of Regulation of SR no. $281 / 2003$

The large number of coagulase negative Staphylococcus isolates obtained is indicative of their particular ability to colonize materials and/or resist cleaning and disinfection operations. They have been shown to predominate on the defeathering machines of a poultry processing site (Mead and Scott, 1994) and have also been isolated from a variety of food processing environments after cleaning and disinfection (Holah et al., 2002; Mettler and Carpentier, 1998 and Bagge-Ravn et al., 2003)
Table 5 Determination of TVC in November 2014

\begin{tabular}{lcc}
\hline Samples & \multicolumn{2}{c}{ TVC $\left(\right.$ CFU.cm $\left.{ }^{-2}\right)$} \\
\hline & Petrifilm plate & Swab method \\
$\mathbf{1}$ & $<10$ & $<10$ \\
$\mathbf{3}$ & $<10$ & $<10$ \\
$\mathbf{4}$ & $<10$ & $\mathbf{1 . 2 5} \times \mathbf{1 0}^{\mathbf{1}}$ \\
$\mathbf{5}$ & $<10$ & $\mathbf{3 . 2 5} \times \mathbf{1 0}^{\mathbf{1}}$ \\
$\mathbf{6}$ & $<10$ & $<10$ \\
& $<10$ & $<10$ \\
\hline
\end{tabular}

Values of CB obtained in November by Petrifilm plates and by swabbing method were after disinfection lower than 1 CFU.cm ${ }^{-2}$ in all samples (ta. 6).

Aycicek et al. (2006) were used Adenosine triphosphate (ATP) bioluminescence and traditional microbiological swabbing culture methods for detection of surface hygiene on worktops, cutting boards and equipments at a hospital kitchen. In their study, 280 samples from 14 different surfaces in the hospital kitchen were examined such as steel, polyethylene plastic, wooden and marble workbenches (vegetable, meat, bakery preparing), meat grinder, mash machine, polyethylene plastic meat and vegetable chopping workbenches, meat and vegetable knives, gastronome basin, tap head, oven handle. Of the results, $2.5 \%$ that were evaluated "clean" by ATP measurement were confirmed clean by the microbiological technique; on the other hand, $37.1 \%$ of the results that were evaluated "clean" by the microbiological technique were determined "dirty" by the ATP measuring technique. $97.5 \%$ of the results that were evaluated "clean" by ATP measurement technique was determined "clean" by microbiological technique, on the other hand $62.9 \%$ of the results that were evaluated "clean" by the microbiological technique were determined "clean" by the ATP measuring technique.

Table 6 Determination of CB in November 2014

\begin{tabular}{lcc}
\hline Samples & \multicolumn{2}{c}{ CB $\left(\right.$ CFU.cm $\left.{ }^{-2}\right)$} \\
\hline & Petrifilm plate & Swab method \\
$\mathbf{1}$ & $<1$ & $<1$ \\
$\mathbf{2}$ & $<1$ & $<1$ \\
$\mathbf{3}$ & $<1$ & $<1$ \\
$\mathbf{4}$ & $<1$ & $<1$ \\
$\mathbf{5}$ & $<1$ & $<1$ \\
$\mathbf{6}$ & $<1$ & $<1$ \\
\hline
\end{tabular}

Balzaretti and Marzano (2013) evaluated the hygienic standards of 44 foodservice facilities by monitoring the food contact surfaces $(\mathrm{n}=302)$, and food handlers $(\mathrm{n}=287)$. The hygienic standard of surfaces was sufficiently high. Only $7.9 \%$ of surfaces did not conform with advisory standards in terms of total coliforms, and $2.6 \%$ were found to be contaminated with Enterococcus spp. at $\geq 1.0 \log$ CFU. $\mathrm{cm}^{-2}$. The hygienic standard of washed and disinfected hands of food workers was not adequately high: the total bacterial count and coagulase positive Staphylococci exceeded the satisfactory limit in $8.4 \%$ and $3.5 \%$ of cases, respectively.

\section{CONCLUSION}

Total viable count and number of coliform bacteria were determined from selected surfaces at meat processing after disinfection during three month. Two methods for monitoring the efficiency of disinfection were used - swabing method and $3 \mathrm{M}^{\mathrm{TM}}$ Petrifilm ${ }^{\mathrm{TM}}$ plates. Our results show, that swabbing method is more sensitive in compare with $3 \mathrm{M}^{\mathrm{TM}}$ Petrifilm ${ }^{\mathrm{TM}}$ plates.

A major goal for the food processing industry is to provide safe, wholesome and acceptable food to the consumer. Control of microorganisms is essential to meeting this goal. This control is partly exerted through processing and preservation techniques that eliminate microorganisms or prevent their growth.

Acknowledgments: The paper was supported by the project: The research leading to these results has received funding from the European Community under project no 26220220180: Building Research Centre „AgroBioTech“

\section{REFERENCES}

AYCICEK, H., OGUZ, U., KARCI, K. 2006. Comparison of results of ATP bioluminescence and traditional hygiene swabbing methods for the determination of surface cleanliness at a hospital kitchen. International Journal of Hygiene and $\begin{array}{llllll}\text { Environmental Health, } 209 & \text { (2), } 203 & \text { to } 206 .\end{array}$ http://dx.doi.org/10.1016/j.ijheh.2005.09.007

BAGGE-RAVN, D., NG, Y., HJELM, M., CHRISTIANSEN, J.N., JOHANSEN,

C., GRAM, L. 2003. The microbial ecology of processing equipment in different fish industries-analysis of the microflora during processing and following 
cleaning and disinfection. International Journal of Food Microbiology, 87 (3), 239-250. http://dx.doi.org/10.1016/s0168-1605(03)00067-9

BALZARETTI, C.M. - MARZANO, M.A. 2013. Prevention of travel-related foodborne diseases: Microbiological risk assessment of food handlers and readyto-eat foods in northern Italy airport restaurants. Food control, 29 (1), 202-207. http://dx.doi.org/10.1016/j.foodcont.2012.05.077

BAZACO, M.C., EIFERT, J.D., WILLIAMS, R.C., KATHARIOU, S. 2007. Quantitative recovery of Listeria monocytogenes and select Salmonella serotypes from environmental sample media. Journal of Aoac International, 90 (1), 250257.

BIZZARO, S., DENEUVE, L., VENDEUVRE, J.L. 1990. Etude de la contamination microbienne des surfaces en entreprise. Viandes et Produits Carnés, 11, 220

DAVIDSON, C.A., GRIFFITH, C.J., PETERS, A.C., FIELDING, L.M. 1999 Evaluation of two methods for monitoring surface cleanliness - ATP bioluminescence and traditional hygiene swabbing. Luminescence, 14 (1), 3338. $\quad$ http://dx.doi.org/10.1002/(sici)1522-7243(199901/02)14:1<33::aidbio514>3.0.co;2-i

FEDIO, W.M., WENDAKOON, C.N., ZAPATA, R., CARRILLO, C., BROWNING, P. 2008. Comparison of petrifilm (TM) staph express count system with the bacteriological analytical manual direct-plating method for enumeration of Staphylococcus aureus in artificially contaminated hard cheese. Journal of Aoac International, 91 (5), 1138-1141.

FONNESBECH VOGEL, B., HUSS, H.H., OJENIYI, B., AHRENS, P., GRAM, L. 2001. Elucidation of Listeria monocytogenes contamination routes in coldsmoked salmon processing plants detected by DNA-based typing methods. Applied Environmental Microbiology, 67 (6), 2586-2595. http://dx.doi.org/10.1128/aem.67.6.2586-2595.2001

FRANK, J.F., KOFFI, R.A. 1990. Surface-adherent growth of Listeria monocytogenes is associated with increased resistance to surfactant sanitizers and heat. Journal of Food Protection, 53 (7), 550-554.

HOLAH, J.T., TAYLOR, J.H., DAWSON, D.J., HALL, K.E. 2002. Biocide use in the food industry and the disinfectant resistance of persistent strains of Listeria monocytogenes and Escherichia coli. Journal of Applied Microbiology, 92 (1), 111S-120S. http://dx.doi.org/10.1046/j.1365-2672.92.5s1.18.x

JESSEN, B., LAMMERT, L. 2003. Biofilm and disinfection in meat processing plants. International Biodeterioration and Biodegradation, 51 (4), 265-269. http://dx.doi.org/10.1016/s0964-8305(03)00046-5

KUSUMANINGRUM, H.D., RIBOLDI, G., HAZELEGER, W.C., BEUMER, R.R. 2003. Survival of foodborne pathogens on stainless steel surfaces and cross-contamination to foods. International Journal of Food Microbiology, 85 (3), 227-236. http://dx.doi.org/10.1016/s0168-1605(02)00540-8

MAROUANI-GADRI, N., AUGIER, G., CARPENTIE, B. 2009 Characterization of bacterial strains isolated from a beef-processing plant following cleaning and disinfection - Influence of isolated strains on biofilm formation by Sakaï and EDL 933 E. coli O157:H7. Journal of Food Microbiology, 133

$(1-2)$

62

http://dx.doi.org/10.1016/j.ijfoodmicro.2009.04.028

MARTINON, A., CRONIN, U.P., QUEALY, J., STAPLETON, A., WILKINSON, M.G. 2012. Swab sample preparation and viable real-time PCR methodologies for the recovery of Escherichia coli, Staphylococcus aureus or Listeria monocytogenes from artificially contaminated food processing surfaces. Food Control, 24 (1-2), 86-94. http://dx.doi.org/10.1016/j.foodcont.2011.09.007 MATTILA, T., MANNINEN, M., KYLASIUROLA, A.L. 1990. Effect of cleaning-in-place disinfectants on wild bacterial strains isolated from a milking line. Journal of Dairy Research, 57 (1), 33-39. http://dx.doi.org/10.1017/s0022029900026583

MEAD, G.C., SCOTT, M.J. 1994. Coagulase-negative staphylococci and coliform bacteria associated with mechanical defeating of poultry carcasses Letters in Applied Microbiology, 18 (1), 62-64. http://dx.doi.org/10.1111/j.1472765x.1994.tb00803.x

METTLER, E., CARPENTIER, B. 1998. Variations over time of microbial load and physicochemical properties of floor materials after cleaning in food industry premises. Journal of Food Protection, 61 (1), 57-65.

MOORE, G., GRIFFITH, C. 2002a. A comparison of surface sampling methods for detecting coliforms on food contact surfaces. Food Microbiology, 19 (1), 6573. http://dx.doi.org/10.1006/fmic.2001.0464

MOORE, G., C. GRIFFITH, C. 2002b. Factors influencing recovery of microorganisms from surfaces by use of traditional hygiene swabbing. Dairy, Food, and Environmental Sanitation, 22 (6), 410-421.

MOORE, G., GRIFFITH, C. 2002c. Factors influencing recovery of microorganisms from surfaces by use of traditional hygiene swabbing. Dairy Food, and Environmental Sanitation, 22 (6), 410-421.

MOORE, G., GRIFFITH, C. 2007. Problems associated with traditional hygiene swabbing: the need for in-house standardization. Journal of Applied Microbiology, $103 \quad$ (4), 1090-1103. http://dx.doi.org/10.1111/j.13652672.2007.03330.x

OULAHAL-LAGSIR, N., MARTIAL-GROS, A., BONNEAU, M., BLUM, L.J. 2000. Ultrasonic methodology coupled to ATP bioluminescence for the noninvasive detection of fouling in food processing equipment — validation and application to a dairy factory. Journal of Applied Microbiology, 89 (3), 433-441. http://dx.doi.org/10.1046/j.1365-2672.2000.01132.x

PAULSEN, P., BORGETTI, C., SCHOPF, E., SMULDERS, F.J.M. 2008 Enumeration of Enterobacteriaceae in various foods with a new automated mostprobable-number method compared with Petrifilm and international organization for standardization procedures. Journal of Food Protection, 71 (2), 376-379.

REGULATION OF SLAOVAK REPUBLIC NO. 281/2003 aboutthe requirements for the protection of human health in the production and marketing of fresh meat on the market.

RIGARLSFORD, J.F. 2007. Microbiological monitoring of cleaning and disinfection in food plants. Microbiological Analysis of Red Meat, Poultry and Eggs, 165-182. http://dx.doi.org/10.1533/9781845692513.165

VERRAN, J., BOYD, R.D., HALL, K., WEST, R.H. 2001. Microbiological and chemical analyses of stainless steel and ceramics subjected to repeated soiling and cleaning treatments. Journal of Food Protection, 64 (9), 1377-1387.

VICOSA, G.N., MORAES, P.M., YAMAZI, A.K., NERO, L.A. 2010 Enumeration of coagulase and thermonuclease-positive Staphylococcus spp. in raw milk and fresh soft cheese: an evaluation of Baird-Parker agar, Rabbit Plasma Fibrinogen agar and the Petrifilm (TM) Staph Express count system Food Microbiology, 27 (4), 447-452. http://dx.doi.org/10.1016/j.fm.2009.12.007 WILKS, S.A., MICHELS, H., KEEVIL, C.W. 2005. The survival of Escherichid coli $\mathrm{O} 157$ on a range of metal surfaces. International Journal of Food Microbiology, $105 \quad$ (3), 445-454. http://dx.doi.org/10.1016/j.ijfoodmicro.2005.04.021 